\title{
天然ダム越流決壊に伴う流出流量変動 に関する研究 STUDY ON OUTFLOW FLUCTUATION CAUSED BY LANDSLIDE DAM COLLAPSE
}

\author{
赤澤史顕1・池田亮和 2 ・里深好文 3 \\ Fumiaki AKAZAWA, Akikazu IKEDA and Yoshifumi SATOFUKA \\ 1学生会員 修(工) 立命館大学 理工学研究科（广525-8577 滋賀県草津市野路東1-1-1） \\ 2非会員 立命館大学 理工学研究科（干525-8577 滋賀県草津市野路東1-1-1） \\ 3 正会員 工博 立命館大学 理工学研究科 教授（干525-8577 滋賀県草津市野路東1-1-1）
}

\begin{abstract}
Recently, climate change has resulted in an increasing number of heavy rainfall events. Heavy rainfalls tend to cause large-scale landslides and create large landslide dams. Large landslide dams retain a large amount of water and often burst causing floods and catastrophic damage in the downstream area. Therefore, the study of landslide dam deformation is essential for predicting potential floods to implement effective flood risk management. To understand the landslide dam deformation process and dam outflow discharge characteristics, we carried out flume experiments of landslide dam erosion by overtopping flow. In the flume experiments, we observed the landslide dam deformation process directly. We found that dam height and inflow discharge affect to outflow discharge. Secondly, we developed a numerical model to simulate landslide dam erosion by overtopping flow. To improve the prediction of the outflow discharge, we incorporated the inertial debris flow model, the side bank erosion model, and the slope collapse model into our numerical model. The resulting proposed model is tested by comparing the results of simulation with experiment data. In addition, we organized experimental data by dimensionless quantity and it may indicated that peak outflow is expressed by dam height and inflow discharge.
\end{abstract}

Key Words : Landslide dam, flood prediction, inertial debris flow, numerical simulation

\section{1. はじめに}

近年, 日本では地球温暖化のためか高強度の降雨が発 生する頻度が高くなってきている. 高強度の降雨は大規 模な斜面崩壊を引き起こし, 時として河川をせき止め, 天然ダムを形成する. 多量の水を貯めた天然ダムが決壊 すると，その水が一気に下流へと流孔出し，下流域にお いて洪水が発生し，甚大な被害を引き起こす危険性があ る。したがって, 天然ダム決壊による下流への被害を軽 減するためには, 決壊に伴う天然ダム下流への洪水流出 を的確に予測し，下流域に対して危険性を伝える必要が ある。

これまでに, 天然ダムの越流決壊による下流への流出 流量を予測するため, 様々な研究が行われてきた. 実験 に関しては高橋ら卢や小田ら $ら^{2)}$ によるものがある. 高橋1) らは天然ダムに関する水路実験を行い，その侵食形状と
流出流量を計測し, 洪水流出は水路の勾配と貯留水量に 影響されることを示した. 小田ら ${ }^{2)}$ は土の粘着力の影響 を調べるため, ベントナイトを実験に使用し，粘着力が ある場合，流量のピークは小さくなることを示した．計 算モデルに関しては高橋ら ${ }^{1)}$ 里深ら $^{33}$ によるもの゙ある. 高橋ら ${ }^{1}$ は，天然多ムが決壊する際に多様な流砂形態を とると予想し，掃流砂，掃流状集合流動，石碩型土石流 を考え，側岸侵食を含めた越流決壊に関する二次元のモ

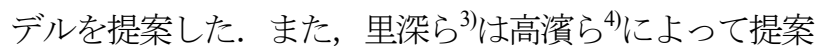
された二層流モデルに流速の1乗に比例する側岸侵食モ デルを組み込んだ天然ダムの一次元計算モデルを提案し， 実際の天然ダムの越流侵食事例に適用し，その洪水流出 過程が再現できることを示している.

一方で, 天然ダムの決壊過程について着目し，実験し た例はそれほど多くなく，また，天然ダムの形の違いや 流入流量の違いに着目して，いくつもの条件下で実験を 行う試みはこれまであまり行われていない，そこで，本 
研究では，ダムの形状については縦断形状として三角形 と台形の2通り，ダム高さを 3 通り，流入流量を 2 通りに 変化させて水路実験を行い，それらが流出流量に与える 影響を調べた，それに加えて，水路実験の再現計算を 行った. 計算では二次元流れのモデルに多様な流砂形態 を想定するため, 高橋ら5)の慣性土石流モデル，側岸侵 食モデル，土砂の崩落モデルを導入した．計算結果と実 験の決壊過程, 流出過程とを比較し, その適用性を検討 した.

最後に一般的な天然ダム決壊によるピーク流量の推定 に資するよう，実験から得られた結果をもとに，無次元 量で整理し, 実際の天然ダムの事例, 既往研究による現 地実験から得られたデータ, 計算モデルによる条件を変 えて行った計算の結果をプロットした.

\section{2. 天然ダムに関する水路実験とその流出過程に}

\section{関する考察}

\section{（1）実験概要}

底面幅 $18 \mathrm{~cm}$ ，水路勾配 0.1 の長方形断面水路に図-1, 図-2示す形状で天然ダムを作成する．水路側壁はガラス で水路床は滑らかである．行った実験ケースを表-1に示 す．実験は三角形状の天然ダムを基本とした．実験ケー スCase1〜3は三角形状の天然ダムの高さの違いによる検 討を行うためのもので, Case4は形状の違いによる検討 を行うためのもの，Case5は流入流量の違いを検討する ためのものである. 天然ダムの上下流の法勾配は図-1に 示すとおり全ケース同じ勾配としている。 なお，実験は 全てのケースに対してそれぞれ2，3回行った．天然ダム を作成する際には, 出来る限り実験に再現性を持たせる ため，土砂を $1.0 \mathrm{~cm}$ 毎の層状に積み重ねて作成した。 天 端の右岸沿いには幅 $1.0 \mathrm{~cm}$, 深さ $1.0 \mathrm{~cm}$ の切欠きを作り, そこから越流させることとした，側壁に沿って越流させ ることにより，天然ダムの侵食過程を容易に観察できる。 天然ダムを作成する際に使用した材料は平均粒径 $0.25 \mathrm{~mm}$ のほぼ均一な粒径をもつ珪砂である. 水は水路 の上流に設置してあるタンクから一定の量で供給した。

流出流量の時間変化は水路の横からカメラでダム上流 の堪水位の時間変化を計測し，それを基に計算した。 こ の計算では天然ダムが侵食された際の土砂の量が考慮さ れておらず, 水のみの流量となっている.しかし, 流出 する水量に対し，侵食される土砂の量はそれほど大きく なく, また水路下流端においても直接土砂と水を採取し ており，二つの測定法であまり結果に差がないことを確 認している. 越流開始時間については水が切欠き部の下 流端からダムの下流法面に流れた時点とした。 天然ダム の侵食過程や越流流れの水面幅については, ビデオカメ ラの映像をもとに計測した。

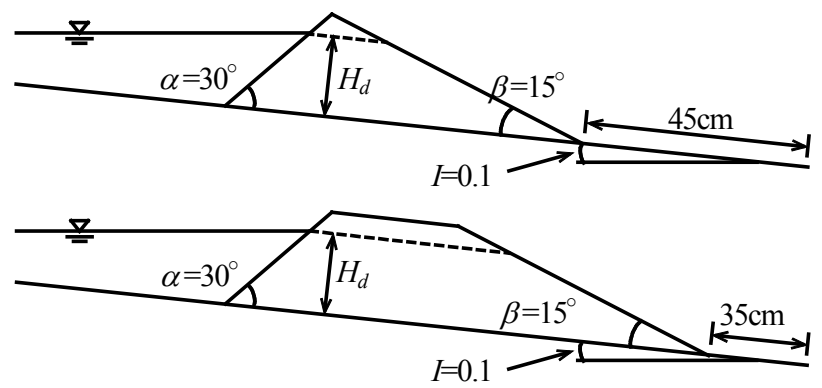

図-1 水路実験状況 (上:三角形, 下:台形)

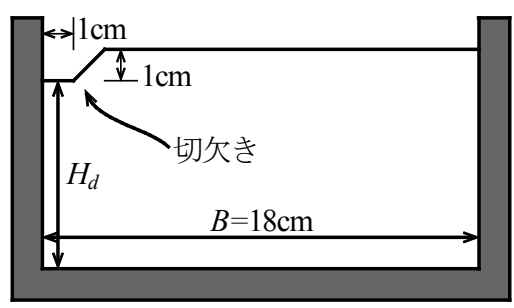

図-2 水路実験ダム横断図

表-1 水路実験ケース

\begin{tabular}{|c|c|c|c|}
\hline 実験ケース & $\begin{array}{c}\text { ダム高さ } \\
H_{d}(\mathrm{~cm})\end{array}$ & ダムの形状 & $\begin{array}{c}\text { 流入流量 } \\
\left(\mathrm{cm}^{3} / \mathrm{s}\right)\end{array}$ \\
\hline \hline Case1 & $6.5 \mathrm{~cm}$ & 三角 & 17 \\
\hline Case 2 & $9.0 \mathrm{~cm}$ & 三角 & 17 \\
\hline Case3 & $4.0 \mathrm{~cm}$ & 三角 & 17 \\
\hline Case 4 & $6.5 \mathrm{~cm}$ & 台形 & 17 \\
\hline Case 5 & $6.5 \mathrm{~cm}$ & 三角 & 34 \\
\hline
\end{tabular}

\section{（2）実験結果}

天然ダム上流には通水開始から水が堪水していき，ダ ム天端に到達すると，切欠き部から水が越流し決壊した。 実験は全てのケースにおいて越流により決壊を生じた。 図-3にCase1〜5の越流開始後の流出流量を示し, 図-4に Case1, Case4, Case5の越流開始から10秒毎の侵食過程 を示した．実験はそれぞれのケース毎に2，3回行ってい るが，回数毎に結果はそれほど変わらなかった，そのた め，そのうちひとつのケースについてそれぞれ図-3，図 -4に示している.

Case1の実験開始から実験終了までの状況について以 下に述べる。図-3，図-4より，天然ダムの下流法面は越 流開始加ら越流水によって徐々に侵食され，20秒後から ダム高さは急に小さくなり始め, それとともに流出流量 が大きくなった. 45秒後には流出流量のピークがあらわ れ，60秒後には決壊はほぼ終了していた。

天然ダム内部の水分状態に関しては，実験開始から堪 水位が上昇する際に，天然ダム内部の湿潤線が上流から 下流へ徐々に進んでいくことが水路側壁からの観察に よって確認された．また，水路上方からの観察により湿 潤線の進行は横断方向にほぼ一様であった。 越流開始時 


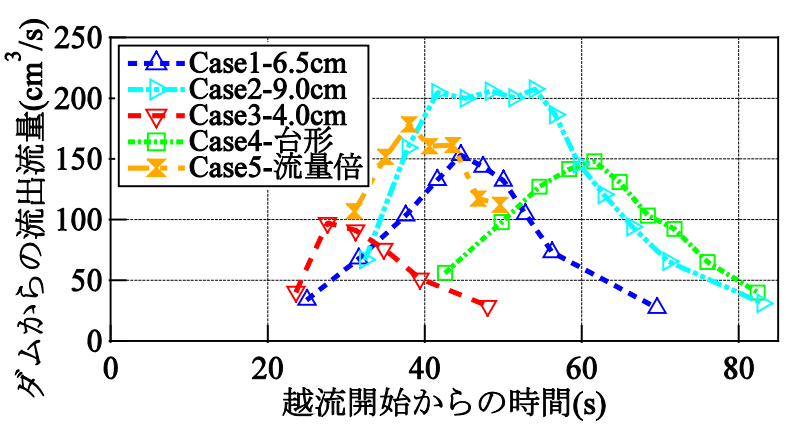

図-3 流出流量の実験值

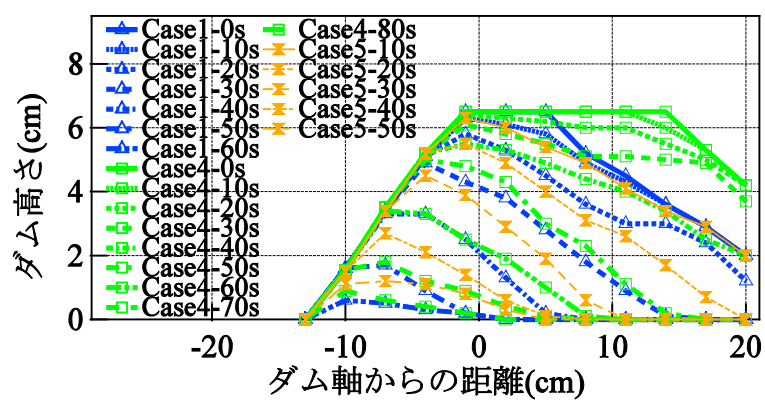

図-4 侵食過程の実験結果（Case1，Case4，Case5）

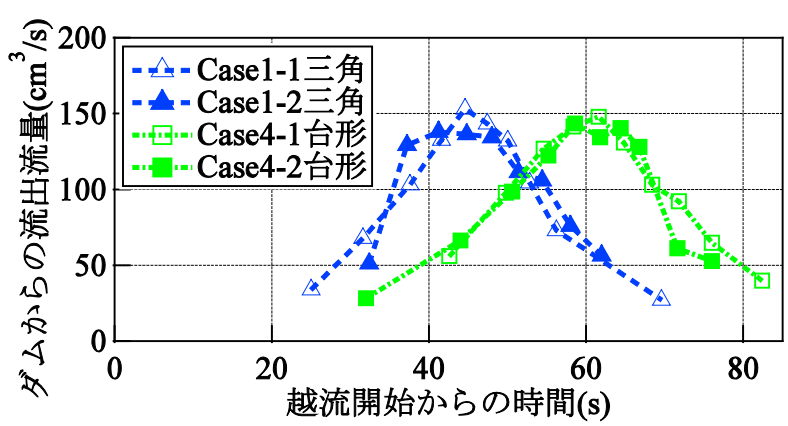

図-5＼cjkstart流出流量の実験値 (Case1，Case4)

には湿潤線の先端はダムの法尻の手前約 $9 \mathrm{~cm}$ 付近の位置 にあった．ダム高さが急に減少し始める20秒の時点では, 側壁に接している部分全体が湿潤していることが観察さ れ，上方からの観察より水みちから約 $4 \mathrm{~cm}$ 範囲まで湿 潤していることが観察された。これらの結果から，20秒 より後の河床表面はほぼ飽和していたといえる.

\section{（3）実験結果に基づく天然ダムの流出流量の考察}

ダムの高さが違うCase1〜3の流出ピーク流量について 比較すると, 図-3より, ダムの高さが大きいほどピーク 流量が大きくなることが確認された. Case1〜3それぞれ のピーク流量は $153 \mathrm{~cm}^{3} / \mathrm{s}, 207 \mathrm{~cm}^{3} / \mathrm{s}, 97 \mathrm{~cm}^{3} / \mathrm{s}$ となり，ダ ム高さにほぼ比例していた．ピーク流量が発生するまで の時間についてみると, ダムが小さいCase3が早く, ダ ムが大きくなるにつれて遅くなった.

流入流量が違うCase1, Case5について比較すると, Case 5 ではピーク流量が $178 \mathrm{~cm}^{3} / \mathrm{s}$ となり，流入流量が大き
い方がピーク流量が大きくなることが分かった．これは 図-4に示してあるように，流入流量が大きくなることに より，ダム高さの低下速度が大きくなったためだと考え られる，そのため，流入流量が大きいほど，ピーク流量 が発生する時刻も早くなっている.

ダムの形が違うCase1, Case4について比較するため, 図-5にそれぞれ二回分の実験の流出流量を示した．図-5 より，流出ピーク流量はダムが三角形と台形の場合でそ れほど変わらず，台形の場合は流出ピークが発生する時 間が遅くなることがわかる. Case1 とCase4の流出ピーク 流量がそれほど変わらない理由については，図-4に示し ているように，天端付近のダム高さの低下速度がほぼ同 じであるためだと考えられる．また，図-4に示した侵食 過程より，Case4の侵食形状は途中からはCase1の侵食形 状とほぼ同様になることが分かった。これによりCase1 と同じ高さをもつ台形の場合や，同じ高さをもつ下流が 緩い勾配の場合では，終盤の侵食過程は似通ったものに なると考えられる.

\section{3. 越流侵食モデルによる計算と実験の比較}

天然ダムの越流侵食過程について検討するため，越流 水の流れを二次元で計算する越流侵食モデルを開発した.

\section{（1）天然ダムの越流侵食モデル}

天然ダムを水が越流したとき，その越流水の流れによ りダム表面が侵食される. 天然ダム上の流れる越流流れ は以下のような基礎方程式を用いて計算される。

全流量（土砂+水）の質量保存則を以下に示寸.

$$
\frac{\partial h}{\partial t}+\frac{\partial u h}{\partial x}+\frac{\partial v h}{\partial y}=i C_{*}+i_{s} C_{*}
$$

ここに, $h$ は水深, $u$ は方向の断面平均流速, $v$ は $y$ 方 向の断面平均流速，iは河床の侵食・堆積速度， $i_{s}$ は側岸 の侵食速度，C*は河床の容積土砂濃度である.

越流水中の土砂の質量保存則を以下に示寸.

$$
\begin{aligned}
& \frac{\partial C h}{\partial t}+\frac{\partial C u h}{\partial x}+\frac{\partial C v h}{\partial y}+\frac{\partial i_{s} \Delta z C_{*}}{\partial x}+\frac{\partial i_{s} \Delta z C_{*}}{\partial y} \\
& =i C_{*}
\end{aligned}
$$

ここに, $C$ は越流水中の容積土砂濃度， $\Delta z$ は隣接する計 算点との河床高の差である.

$x, y$ 方向の流れの運動方程式を以下に示寸.

$$
\begin{aligned}
& \frac{\partial u}{\partial t}+u \frac{\partial u}{\partial x}+v \frac{\partial u}{\partial y}=-g \frac{\partial(h+z)}{\partial x}-\frac{\tau_{x}}{\rho_{d} h} \\
& \frac{\partial v}{\partial t}+u \frac{\partial v}{\partial x}+v \frac{\partial v}{\partial y}=-g \frac{\partial(h+z)}{\partial y}-\frac{\tau_{y}}{\rho_{d} h}
\end{aligned}
$$

ここに，gは重力加速度， $\tau_{x}$ は $x$ 方向の河床せん断力， $\tau_{y}$ はy方向の河床せん断力, $\rho_{d}$ は越流水の密度である.

河床せん断力に関しては, 掃流砂のときはマニングの 式から，土砂濃度が高いときは高橋ら5゙による慣性土石 
流の抵抗則の近似式を用いている.

掃流砂の場合,

$$
\begin{aligned}
& \frac{\tau_{x}}{\rho h}=\frac{g n_{m}{ }^{2} u \sqrt{u^{2}+v^{2}}}{h^{4 / 3}} \\
& \frac{\tau_{y}}{\rho h}=\frac{g n_{m}{ }^{2} v \sqrt{u^{2}+v^{2}}}{h^{4 / 3}}
\end{aligned}
$$

ここに， $n_{\mathrm{m}}$ はマニングの粗度係数である.

慣性土石流の場合,

$$
\begin{gathered}
\frac{\tau_{x}}{\rho_{T} h}=\frac{u_{*}^{2} u}{h \sqrt{u^{2}+v^{2}}} \\
\frac{\tau_{y}}{\rho_{T} h}=\frac{u_{*}^{2} v}{h \sqrt{u^{2}+v^{2}}} \\
\frac{U}{u_{*}}=F_{1}\left[A_{1}+A_{2} \log _{10}\left(\frac{h}{d_{p}}\right)+A_{3}\left\{\log _{10}\left(\frac{h}{d_{p}}\right)^{2}\right\}\right]
\end{gathered}
$$

ここに， $\rho_{\mathrm{T}}$ は土石流の見かけの密度，Uは平均流速， $u_{*}$ は摩擦速度, $h$ は水深， $d_{p}$ は粒径， $F_{1}, A_{1}, A_{2}, A_{3}$ は係 数であり各係数の求め方については高橋ら ${ }^{5}$ の研究を参 照して頂きたい．高橋ら ${ }^{5}$ は乱流型土石流と石碩型土石 流及び両者の中間的な性質を持つ土石流を慣性土石流と し，その構成則，土砂濃度と抵抗則の近似式を提案して いる．慣性土石流のモデルでは土石流中の水面に近い土 砂濃度の低い 部分を上層, 河床近くの土砂濃度の高い部 分を下層とすることにより, 乱流型, 石碩型, その両者 の中間型の土石流，掃流状集合流動まで扱うことができ る. このモデルにより, 天然ダムの越流決壊における 様々な流砂形態を考慮することができる.

河床の侵食速度は以下の式で計算している.

$$
\begin{aligned}
& \frac{i}{\sqrt{g h}} \\
& =K_{T} \sin ^{3 / 2} \theta\left\{1-\frac{\sigma-\rho}{\rho} C\left(\frac{\tan \phi}{\tan \theta}-1\right)\right\}^{1 / 2} \\
& \left(\frac{\tan \phi}{\tan \theta}-1\right)\left(C_{\infty}-C\right) \frac{h}{d}
\end{aligned}
$$

ここに， $K_{T}$ は定数， $\theta$ は水面勾配， 中は土の内部摩擦角， $C_{\infty}$ は平衡土砂濃度である.

側岸侵食に関しては，高橋ら ${ }^{1)}$ の研究と同様に土石流 や掃流状集合流動でも側岸侵食量は河床に働く掃流力の 関数であると考え, 以下の式により計算する.

$$
\begin{aligned}
& \frac{i_{s}}{\sqrt{g h}} \\
& =K_{s} \sin ^{3 / 2} \theta\left\{1-\frac{\sigma-\rho}{\rho} c\left(\frac{\tan \phi}{\tan \theta}-1\right)\right\}^{1 / 2} \\
& \left(\frac{\tan \phi}{\tan \theta}-1\right)\left(C_{\infty}-C\right) \frac{h}{d}
\end{aligned}
$$

ここに， $K_{s}$ は定数である．ただし，式(11)は比例定数 の部分が高橋ら ${ }^{1)}$ の研究とは異なっている。このような
取扱いをした理由は，高橋ら ${ }^{1)} の$ 研究では側岸に作用す るせん断力は，平均的には河床に作用するせん断力の 1/2としているが，この点に関しては検討の余地が残さ れているためである.

式(10), 式(11)の定数 $K_{T} ， K_{s}$ は值は天然ダムの材料に より異なると考えられる．そこで，本研究では定数 $K_{T}$, $K_{s}$ は值を変化させて試行計算を行い，実駼結果を比較的 良好に再現できる值を採用しているが，定数 $K_{T} ， K_{s}$ の 值の妥当性については今後さらに検討を要する.

平衡土砂濃度は高橋〕による慣性土石流の輸送濃度の 近似式から計算しており，その近似式は以下のように表 わされる。

$$
C_{t r}=a_{1}+a_{2} x+a_{3} x^{2}+a_{4} x^{3}
$$

ここに， $C_{t r}$ は輸送濃度， $x=\sin \theta$ であり $, a_{1}, a_{2}, a_{3}, a_{4}$ は係数であり，それぞれ相対水深 $h / d_{p}$ より計算される. 各係数の求め方については高橋ら 5 の研究を参照して頂 きたい. 式(12)より計算される輸送濃度 $C_{t r}$ を平衡土砂濃 度 $C_{\infty}$ として用いている.

\section{（2）土砂崩落モデル}

天然ダムの越流侵食過程では越流水によって縦方向に 急激に侵食されるとともに，側岸が間欠的に崩落しなが ら，水みちが拡幅し決壊することが示されている．禅野 らのの研究により，側岸崩落の間欠性を考慮した間欠崩 落モデルが提案されているが，本研究では間欠性は考慮 せず，側岸傾斜角がある程度以上になると側岸が崩落す る関根”のモデルを参考にしたシンプルな土砂崩落モデ ルを導入した.

土砂崩落モデルの取り扱いは以下のようにする.

1) 着目する計算点の河床高とその隣接する4点の河床 高に $\Delta y \tan \phi_{c}(\Delta y$ は計算点間隔)を足したものとをそれぞれ 比較することにより，隣接する計算点間の傾斜角が側岸 の崩落角 $\phi_{c}$ を超えているかどうか調べる.

2）崩落角を超える傾斜角をもつ計算点間がある場合は, 土砂の崩落量 $\varepsilon$ を計算する. 崩落量 $\varepsilon$ は下のように計算 する.

$$
\varepsilon=\frac{1}{2}\left\{z_{i, j}-\left(z_{i, j+1}+\Delta y \tan \phi_{c}\right)\right\}
$$

3 ）着目する計算点から土砂が崩落し, 崩落量 $\varepsilon$ で減少 すると考え, 河床高から崩落量 $\varepsilon$ を減じる. 減少した分 は崩落角を超える傾斜角をもつ計算点の方向に土砂が移 動すると考え, その計算点の河床高を崩落量 $\varepsilon$ 分増加さ せる.

以上の処理を各計算時間ステップごとに行っている. 本来なら，土砂が移動する時間も考慮する必要があるが, ここでは簡易的に計算を行うため, 同一ステップで崩落 が終了寸るとしている．側岸が崩落寸る角度 $\phi_{c}$ は実験結 果を参考にして $\phi_{c}=75^{\circ}$ と設定した. 
表-2 計算条件

\begin{tabular}{|c|c|}
\hline パラメータ & 設定值 \\
\hline \hline$x$ 方向の計算点間隔 $d x$ & $0.01 \mathrm{~m}$ \\
\hline$y$ 方向の計算点間隔 $d y$ & $0.002 \mathrm{~m}$ \\
\hline 計算の時間刻み $d t$ & $0.002 \mathrm{~s}$ \\
\hline 水の密度 $\rho$ & $1.0 \mathrm{~g} / \mathrm{cm}^{3}$ \\
\hline 砂砶の密度 $\sigma$ & $2.65 \mathrm{~g} / \mathrm{cm}^{3}$ \\
\hline 平均粒径 $d_{\mathrm{m}}$ & $0.25 \mathrm{~mm}$ \\
\hline 河床の容積濃度 $C *$ & 0.65 \\
\hline 内部摩擦角 $\tan \phi$ & 0.781 \\
\hline 侵食速度係数 $K_{\mathrm{T}}$ & 0.002 \\
\hline 側岸侵食速度係数 $K_{\mathrm{S}}$ & 0.021 \\
\hline 流入流量 $q_{\mathrm{in}}$ & $17 \mathrm{~cm}^{3} / \mathrm{s}$ \\
\hline
\end{tabular}

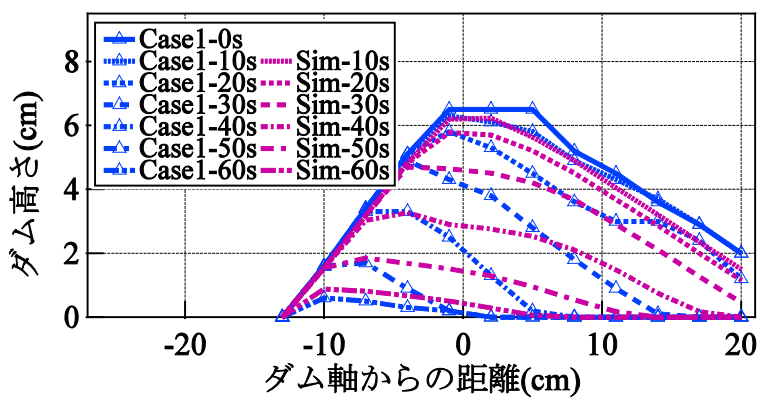

図-6＼cjkstart侵食過程の実験値と計算結果

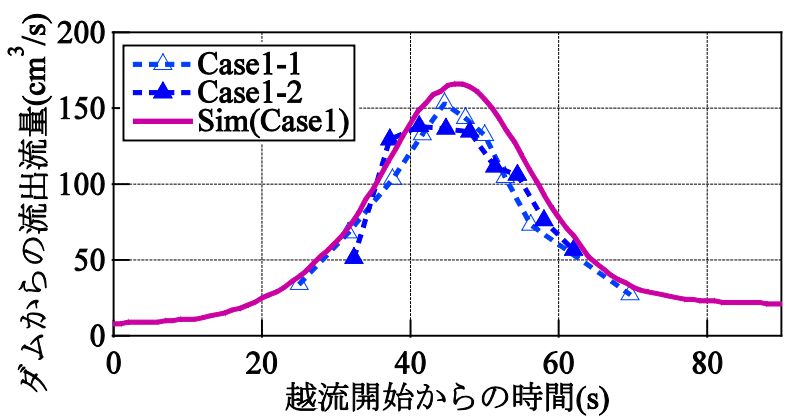

図-7 流出流量の実験值と計算結果

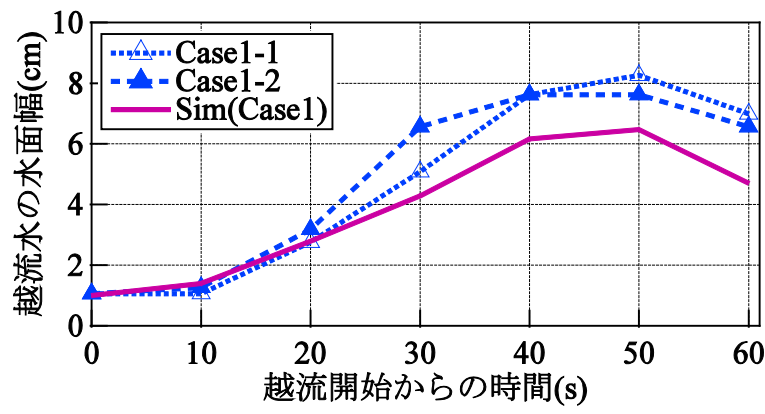

図-8 越流水の水面幅の実験値と計算結果

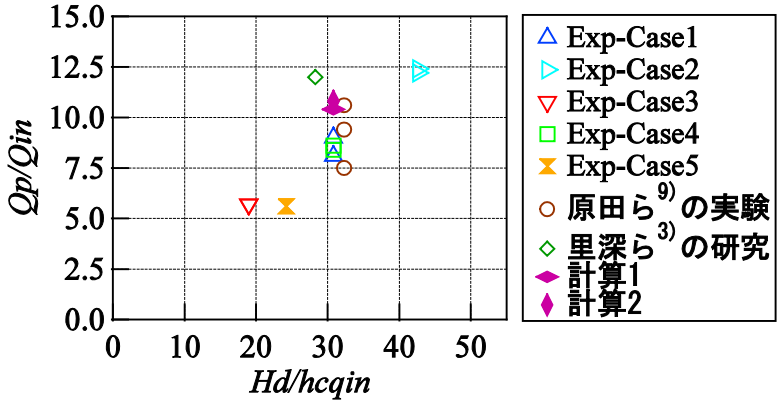

図-9 Qp $/ \mathrm{QincHd} / \mathrm{h}_{\text {cain }}$ (式（12）による）の比較

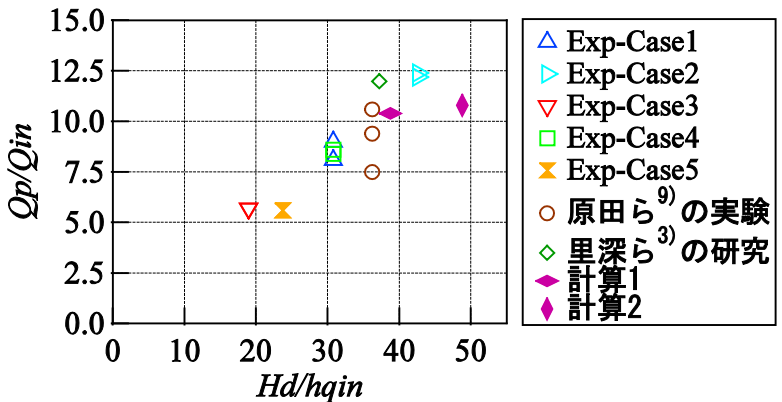

図-10 Qp $/ Q$ inとHd $/ h_{\text {ain }}$ (式（13）による）の比較

(3) 計算条件

先に示した基礎方程式を用いて，前章の水路実験の Case1に対応する条件で数值計算を実行した。計算条件 は，表-2に示すとおりである。

\section{（4）計算結果}

図-6は水路実験のCase1の侵食形状と計算值を比較し たものである. 形状はそれぞれ10秒毎に示されている. 図に示されているとおり，下流の方は若干ずれがあるも のの，流出流量に大きく影響するダム天端付近は良好に 計算できていることが分かった。

図-7は流出流量の水路実験のCase1の実験值と計算值 を比較したものである. 流出ピークや流出流量の波形が 良く再現されている.

図-8には越流水の水夕ち幅の実験值と計算值を示して いる. 水みちの変化が概ね再現出来ている.

\section{4. 越流決壊におけるピーク流量の考察}

水路実験により，越流決壊におけるピーク流量はダム の高さと流入流量に強く影響をうけることが分かったの で，それらの量を無次元化して整理した。 その結果を図 -9 , 図-10に示す. 縦軸には流出ピーク流量 $Q_{p}$ を流入流 量 $Q_{i n}$ で無次元化したものを，横軸にはダム高さ $H_{d}$ を流 入流量から得られる水深で無次元化したものとしている. 流入流量から得られる水深は2通りの方法で求めた。ひ とつは式(12)の芦田ら ${ }^{8)}$ によるレジーム則により越流幅を 
表-3＼cjkstart図-9, 10にこプロットしたデータ

\begin{tabular}{|c|c|c|c|c|c|}
\hline$H_{\mathrm{d}}$ & $q_{\text {in }}$ & $Q_{p}$ & $d$ & $i$ & 備考 \\
\hline $6.5 \mathrm{~cm}$ & $17 \mathrm{~cm}^{3} / \mathrm{s}$ & $\begin{array}{l}153 \mathrm{~cm}^{3} / \mathrm{s} \\
138 \mathrm{~cm}^{3} / \mathrm{s}\end{array}$ & $0.25 \mathrm{~mm}$ & 0.1 & $\begin{array}{l}\text { 実験 } \\
\text { Case1 } \\
\end{array}$ \\
\hline $9.0 \mathrm{~cm}$ & $17 \mathrm{~cm}^{3} / \mathrm{s}$ & $\begin{array}{l}190 \mathrm{~cm}^{3} / \mathrm{s} \\
194 \mathrm{~cm}^{3} / \mathrm{s}\end{array}$ & $0.25 \mathrm{~mm}$ & 0.1 & $\begin{array}{c}\text { 実験 } \\
\text { Case2 }\end{array}$ \\
\hline $4.0 \mathrm{~cm}$ & $17 \mathrm{~cm}^{3} / \mathrm{s}$ & $\begin{array}{l}97 \mathrm{~cm}^{3} / \mathrm{s} \\
97 \mathrm{~cm}^{3} / \mathrm{s}\end{array}$ & $0.25 \mathrm{~mm}$ & 0.1 & $\begin{array}{c}\text { 実験 } \\
\text { Case3 }\end{array}$ \\
\hline $6.5 \mathrm{~cm}$ & $17 \mathrm{~cm}^{3} / \mathrm{s}$ & $\begin{array}{l}147 \mathrm{~cm}^{3} / \mathrm{s} \\
143 \mathrm{~cm}^{3} / \mathrm{s}\end{array}$ & $0.25 \mathrm{~mm}$ & 0.1 & $\begin{array}{l}\text { 実験 } \\
\text { Case4 }\end{array}$ \\
\hline $6.5 \mathrm{~cm}$ & $34 \mathrm{~cm}^{3} / \mathrm{s}$ & $\begin{array}{l}196 \mathrm{~cm}^{3} / \mathrm{s} \\
196 \mathrm{~cm}^{3} / \mathrm{s}\end{array}$ & $0.25 \mathrm{~mm}$ & 0.1 & $\begin{array}{l}\text { 実験 } \\
\text { Case5 }\end{array}$ \\
\hline $90 \mathrm{~cm}$ & $16 \mathrm{l} / \mathrm{s}$ & $\begin{array}{l}170 \mathrm{l} / \mathrm{s} \\
150 \mathrm{l} / \mathrm{s} \\
120 \mathrm{l} / \mathrm{s} \\
\end{array}$ & $1.5 \mathrm{~mm}$ & 0.105 & $\begin{array}{c}\text { 原田ら } \\
\text { の実験 }\end{array}$ \\
\hline $57 \mathrm{~m}$ & $1500 \mathrm{~m}^{3} / \mathrm{s}$ & $\begin{array}{c}18000 \\
\mathrm{~m}^{3} / \mathrm{s} \\
\text { (計算值) }\end{array}$ & $0.35 \mathrm{~cm}$ & 0.007 & $\begin{array}{c}\text { 里深 } 5^{3)} \\
\text { の研究 }\end{array}$ \\
\hline $65 \mathrm{~cm}$ & $5.3 \mathrm{l} / \mathrm{s}$ & $55.99 \mathrm{l} / \mathrm{s}$ & $2.5 \mathrm{~mm}$ & 0.1 & 計算值1 \\
\hline $6.5 \mathrm{~m}$ & $1.7 \mathrm{~m}^{3} / \mathrm{s}$ & $18.3 \mathrm{~m}^{3} / \mathrm{s}$ & $2.5 \mathrm{~cm}$ & 0.1 & 計算值2 \\
\hline
\end{tabular}

求めて限界水深を $h_{\text {cqin }}$ とする方法, もうひとつは式(13) のレジーム則より水深 $h_{q i n}$ を求める方法である. 図-9は $h_{\text {cqin }}$ として前者を用いて整理したものを，図-10は $h_{q i n}$ と して後者を用いて整理したものを示している. また，図 -9, 図-10は里深ら 3 によるる実際の天然ダムのデータ，原 田ら にによる現地実験データ，前章に示した計算モデル による条件を変えて行った計算結果も上記の無次元量に より整理しプロットしている. 図-9, 図-10にプロット したデータは表-3に示している.

$$
\begin{gathered}
B=\alpha\left(\frac{Q}{\sqrt{g d i}}\right)^{1 / 2} \\
h=\beta Q^{0.36}
\end{gathered}
$$

$B$ は水面幅， $\alpha, \beta$ は係数 $(\alpha=1.7, \beta=0.11), Q$ は流量 （ピーク流量を代入する），dは粒径，iは勾配である.

図-9，10より，結果に多少バラつきがあるものの，全 体として $H_{d} / h の$ 増加に伴い， $Q_{p} / Q_{i n}$ が増加していること がわかる．前章の計算モデルによる計算結果も実験結果 とほぼ同じところにプロットされた，また，図-9と図10を比較してみると, 両者はそれほど変わらなかった. しかし，式(13)による方法では，粒径や河床勾配を考慮 できないため, 式(12)の方がより適用性が広い可能性が ある.ただし， $H_{d} / h_{c q i n}, H_{d} / h_{q i n}$ が図-9，10の範囲よりも さらに大きい場合，ダムの大きさに対し流入流量が小さ くなり過ぎれば，ダムがほとんど侵食されないことが想 定される.この点については, 今後検討が必要である.

\section{5. おわりに}

本研究の結果を以下にまとめる.
天然ダムに関する水路実験により，ダムの決壊時の流 出ピーク流量はダム高さ, 流入流量に大きく影響される ことが分かった. ダムの形状（三角形，台形）について は，ダムの高さが同じ場合，形状によって流出ピーク流 量の大きさは変化せず，台形の場合は流出ピークが発生 する時間が遅くなることが分かった。 また, 台形のダム の侵食過程は途中から，三角形のダムと似通ったものに なり，ハイドログラフも同様の波形を示した.

水路実験の再現計算を行った. 高橋らによる慣性土石 流モデル，側岸侵食モデル，土砂崩壊のモデルを導入し た計算により，天然ダムの流出過程を良好に再現できた． 侵食過程については表現できないところがあるものの， 流出流量に大きく影響するダム天端付近のダム高さ, 水 面幅は概ね再現できた。 しかし, 侵食速度, 側岸侵食速 度の定数 $K_{T}, K_{s}$ の普遍的な決定については今後の課題 である.

天然ダムの流出ピーク流量について考察を行った．流 出ピーク流量はダム高さ, 流入流量を用いた無次元量 $Q_{p} / Q_{i n}, H_{d} h_{c q i n}, H_{d} / h_{q i n}$ により, ある程度推定できること が分かった. しかし, 検討例が未だ十分ではないので, 今後さらなる検討が必要と思われる。

\section{参考文献}

1) 高橋 保, 中川 一: 天然ダムの越流決壊によって形成され る洪水・土石流のハイドログラフ，水工学論文集，第37巻， pp.699-704, 1993.

2) 小田 晃, 水山高久, 長谷川祐治, 森 俊男, 川田孝信：天 然ダムの決壊過程と決壊時の流出量に関する実験的研究，砂 防学会誌, Vol.59, No.1, pp.29-34, 2006.

3) 里深好文, 吉野弘祐, 水山高久, 小川紀一郎, 内川龍男, 森 俊男：天然ダムの決壊に伴う洪水流出の予測手法に関する研 究，水工学論文集，Vol.51,p.901-906, 2007.

4) 高濱淳一郎, 藤田裕一郎, 近藤康弘：土石流加掃流状集合 流動に遷移する流れの解析法に関する研究, 水工学論文集, 第44巻, pp.683-686, 2000 .

5) 高橋 保, 里深好文: 石碩型及び乱流型土石流の一般理論と その実用化モデル，砂防学会誌，Vol.55, No.3, pp.33-42, 2002.

6) 禅野浩貴, 岩崎理樹, 清水康行, 木村一郎 : 実物大正面越流 破堤実験の再現計算モデルに関する検討，土木学会論文集 B1(水工学), Vol.68, No.4, I_865-I_870, 2012.

7) 関根正人 : 斜面崩落モデルを用いた網状流路の形成過程シ ミュレーション，水工学論文集，第47巻，p.637-642, 2003.

8) 芦田和男, 江頭進治, 里深好文, 後藤隆之: 網状流路の流路 変動と流砂量, 京都大学防災研究所年報, 第33号 B-2, pp.241-260, 1990.

9) 原田紹臣, 赤澤史顕, 速見 智, 里深好文 : ため池決壊に伴 う洪水流出過程に関寸る研究，土木学会論文集B1(水工学), Vol.69, No.4, I_1213-I_1218, 2013.

(2013. 9. 30受付) 